\title{
GATS and Higher Education: State of Play of the Liberalization
}

\section{Commitments}

\author{
Antoni Verger. Universiteit van Amsterdam
}

\begin{abstract}
Higher education is the education level under the most pressure to be internationally liberalized. Currently, the main global instrument to achieve this liberalization goal is the General Agreement on Trade in Services (GATS) of the World Trade Organization (WTO). In this article, the process of trade liberalization of higher education in the GATS framework is examined. The analysis is divided in two main parts. First, the state of the current situation of higher education liberalization and that of other education sectors are reviewed and compared. Second, the factors that influence the undertaking of liberalization commitments on education, specifically higher education, are analyzed. To make these comparative analyses, EduGATS, a novel index to measure the degree of liberalization of educational services is introduced.
\end{abstract}

Keywords: GATS, WTO, liberalization, privatization, higher education.

\section{Introduction $^{1}$}

Trade in Higher Education has increased its weight in world trade since the nineties. Higher education is the education level outstandingly more present in trade flows (Larsen and Vincent-Lancrin 2002). In fact, higher education has become one of the main services exportation industries in countries such as Australia, New Zealand and the USA (Larsen, Martin et al. 2002). Consequently, some governments and the higher education industry are increasingly interested in the elimination of barriers to education 
trade. One of the main instruments to reach this objective is the General Agreement on Trade in Services (GATS) of the World Trade Organization (WTO).

At present, the 151 member countries of the WTO are negotiating the liberalization of Higher Education and other educational services in the Doha Round framework. Even so, the liberalization of educational services within the GATS took its first steps during the Uruguay Round of GATT (1986-1994), when 28 countries established the first commitments on education liberalization in the framework of a trade agreement.

My research aims to compare higher education liberalization with that of other education sectors, as well as to analyse the causes of the liberalization of Higher Education, and education in its broadest sense, within the GATS. Specifically, the research focuses on the factors that influence the establishment of liberalization commitments. The suggested factors are the economic inequalities between member countries and specific characteristics of these countries' educational systems (level of privatization of educational spending, weight of the private sector, among others). The indicators for each variable are specified below.

The article is divided into four parts. In the first section, the GATS negotiation methodology, its architecture and its contents are briefly examined. Second, by taking into account the data previously presented, I construct the EduGATS index. EduGATS aims to measure the degree of commitment to educational liberalization undertaken by member countries of the WTO. After, the higher education liberalization commitments consolidated by member countries are reviewed and compared to the liberalization commitments undertaken in other education levels (primary, secondary, adults and other). Finally, the factors that influence the liberalization of educational services are analyzed through qualitative and statistical correlation techniques. When making this 
analysis, I will focus on the liberalization commitments consolidated by the WTO member countries. I will not consider the provisional results of the Doha round, as this round, after several deadlines being lost, has not yet finished and, consequently, new commitments have not arisen.

The sources of the primary data are the lists of liberalization commitments on services of the WTO members (which are available in the 'WTO Services Data Base', see: http://tsdb.wto.org/wto/WTOHomepublic.htm), exploratory interviews with trade delegations from member countries (Brazil, Mexico, Venezuela and Chile), position documents on the education sector (USA, Australia, New Zealand, Japan and Switzerland) and documents from the WTO Council for Trade in Services as well as from the Secretariat. The data was collected between June 2005 and June 2006.

\section{Brief introduction to the GATS negotiation process}

The GATS is one of the main agreements of the WTO. Its main aim is to expand the world trade in services by means of establishing a progressively liberalized multilateral framework of principles and rules for trade in services. The GATS promotes the liberalization of twelve service sectors, among which there are the educational services. Services sectors are, in turn, composed by different sub sectors. Higher Education is one of them. Specifically, the educational sub sectors are: 1) primary education; 2) secondary education; 3) higher education; 4) adult education; and 5) other educational services.

The architecture of GATS is more complex than the architecture of trade agreements on goods, due to the technical difficulties associated with the commercialization of services. It has to be acknowledged that services are usually consumed where they are produced and are both produced and consumed 
simultaneously (Francois and Wooton 2000). Given these difficulties, it has been established that there are four modes of trade in services. These are: 1) Cross-border supply: provision of a service at a distance. In the case of education, this mode is seen in e-learning or in other distance learning programmes; 2) Consumption abroad: the consumer - in our case the student - travels to another country to access the service; 3 ) Commercial presence: the service company sets up a subsidiary abroad. For example, a university sets up a campus abroad; 4) Presence of natural persons: a professional (researcher or teacher) travels to a foreign country to provide a service. The liberalization of services is negotiated on the basis of these four modes, hence markets may be opened in one of the modes but not in the other three.

Additionally, it should be pointed out that the liberalization of services stipulated by GATS means the establishment of commitments on trade opening with reference to two clauses: National Treatment and Market Access. The acquisition of commitments on liberalization in terms of National Treatment means accepting that foreign providers benefit from treatment 'not less favorable' conditions than those given to domestic companies. This implies that foreign suppliers cannot be discriminated. While the commitments on Market Access mean the elimination of barriers (rules, regulations laws, etc.) that hinder the entrance of foreign services providers in the domestic market. Referring to National Treatment there are limitations such as: a) Taxes and levies; b) Subsidies and grants; c) Other financial restrictions; d) Requirements on nationality; e) Requirements on residency; f) Qualifications, licenses, standards; g) Requirements on registration; and h) Requirements on authorization. On the other hand, the limitations which may be established/eliminated in Market Access are: a) Number of services suppliers which are allowed access; b) Value of transactions or activity; c) Total number of service transactions or total sum of service production; d) Total number 
of natural persons who may be employed in a sector or by a specific supplier; e) Specific type of legal form or personality of suppliers; and f) Establishment of specific percentages of participation for foreign capital or the total value of foreign investments.

Additionally, there are a series of principles that are not subject to negotiation. This would be the case with the general obligations and disciplines, such as the Most Favored Nation (article II) and Transparency (article III). The Most Favored Nation rule stipulates that each member will immediately and unconditionally assign service suppliers of a foreign country a treatment no less favorable than that given to service suppliers of any other member country, while transparency obliges countries to guarantee service suppliers access to information related to trade in services (laws, regulations, rules, etc.).

The GATS, in contrast to other WTO agreements, is not a closed agreement. Rather, it is a legal framework and a system of rules that allow WTO member countries to adopt commitments on trade liberalization by means of successive negotiating rounds. On paper, GATS only obliges member countries to participate in negotiations; it does not oblige them in the process of such negotiations to liberalize their services.

I now look at various relevant issues to better understand the logic of GATS and the negotiating process.

\section{Methodology of the GATS negotiations}

GATS negotiations take place within the Council for Trade in Services of the WTO (Larsen, Martin et al. 2002). There are different types of negotiations with different contents and procedures that are being developed in the framework of the Council for Trade in Services (rules, domestic regulation, modalities, etc.). Nevertheless, the bulk of the negotiation is centered on trade liberalization. This area is negotiated based on the 
method of demand-offer. It means that during the negotiation period, the member countries demand to the other countries to liberalize those sectors where they have exportation interests. In response to the demands, the countries also present offers of liberalization that are able to be modified depending on the evolution of the negotiation process itself. The round finishes when members present a definitive list of offers that will be integrated in the GATS as a part of the new liberalization commitments of the member countries. All member countries are obliged to submit a list of commitments on liberalization, but they do not have to include improvements with respect to the previous list, nor new commitments on liberalization (Verger, 2008).

The lists of commitments inform us about the degree of opening up to trade that the member countries assume in each of the various service sectors. Concretely, the lists specify the limits that the countries decide to maintain or eliminate in the areas of National Treatment and Market Access. Additionally, the commitments and limitations are expressed in terms of each of the different modes of trade (cross-border supply; consumption abroad; trade presence; presence of natural persons).

At any moment, irrespective of the development of the negotiations underway, countries are able to introduce new commitments on their lists. In contrast, the agreement establishes hurdles to the withdrawal of commitments already established (see article XXI of the GATS). As a result of this, the development of GATS aggravates and blocks a series of pro-market regulatory frameworks (Robertson and Dale 2003b).

\section{EduGATS: Measuring the degree of educational liberalization}

The rationale and the content of the lists of commitments reveal the necessary elements to calculate the degree of liberalization indicated by the lists themselves. Carrying out these calculations is necessary due to that fact that my exploration is developed at two 
analytical levels. In the first, I observe the relation between the independent variables and the establishment ('yes' or 'no') of liberalization commitments in the educational sector from member countries. At the second level of analysis, I observe the relation between the same explicative variables with the 'degree' of commitment to liberalization. In this case, I only contemplate those countries that have adopted some liberalization commitment in education. To realize the analysis at this level means having to effectively measure the degree of commitments that has been established by member countries. To date, measuring the degree of liberalization commitments has not been done in a precise manner. For instance, agencies such as the OECD and the WTO itself usually report on the GATS results referring only to the number of sub sectors committed as a main indicator (OECD 2002b; WTO 2005). Thus, I have constructed a new index for doing this measurement, which I call EduGATS. This index is also useful to compare the liberalization degree of higher education with the liberalization degree of other education levels. Finally, it is worthwhile to mention that the formula to calculate EduGATS could be applied to explore the liberalization degree in other sectors contemplated by GATS. Nevertheless, in this research I apply it exclusively to the education sector and its corresponding sub sectors.

\section{Calculation of EduGATS}

When calculating EduGATS, I take into account the following factors: a) The educational sub sectors committed; b) Limitations in Market Access and National Treatment, which may vary depending on the sub sectors and the four trading modes; and c) Horizontal commitments, which are transversal to the sectorial commitments. The basic premise is that the higher the number of limitations in the lists of 
commitments - see each of the items aforementioned - the lower the degree of trade openness.

The formula to calculate EduGATS considers that, in terms of Market Access, six limitations may be included. Therefore, for each sub sector $(y), M A x=(6-L) / 6$ (where $\mathrm{x}$ makes reference to each trade mode and $\mathrm{L}$ is the number of limitations established, including those present in the horizontal commitments). Additionally, I consider that there are eight possible limitations in National Treatment so that $\mathrm{NTx}=(8$ L)/8. Actually, there are unlimited limitations to National Treatment. However, I consider that eight is an appropriate number because it is the number of National Treatment limitations suggested in the most exhaustive list detected - see (WTO 2000). EduGATS is the result of adding both factors. Once weighted, it may have a value between zero (for totally closed sectors) and one (maximum openness). The resulting formula is: $\mathrm{EduGATS}=\Sigma \mathrm{y}(\mathrm{MAx})+\Sigma \mathrm{y}(\mathrm{NTx})$.

\section{Liberalization of Higher Education. The State of Play}

In recent decades, trade in higher education services has increased much more than trade in other education services. This is reflected in all the modes of supply and in the emergence of a wide range of new 'for profit' providers (OBHE 2002; OBHE 2003; Rodríguez Gómez 2003). Therefore, higher education is the education sector under the much pressure to be internationally liberalized. For instance, in the Doha Round context the unique plurilateral request on education has been focused on Private Higher Education and Other Private Education Services ${ }^{2}$.

Nevertheless, as shall be seen in this section, this trend is not already reflected in the liberalization commitments undertaken in the GATS framework. To date, fiftyseven WTO member countries have included at least one education sub sector in their 
lists of commitments, and forty-eight of them have established commitments in higher education. ${ }^{3}$ In the Figure 1, I show the percentage of sub sectors liberalized by these fifty-seven member countries. As can be seen, higher education is liberalized with the same frequency as secondary education and slightly more than primary education. "Other Educational Services" is not so greatly liberalized probably because, as some negotiators state, it is not clear which kind of education services are contemplated within this category. Finally, Adult Education is slightly more liberalized than higher education.

\section{XXXXXXXXXXXXX FIGURE 1 XXXXXXXXXXXXXXXXXXXXXXX}

When the EduGATS is applied to capture the level of liberalization commitments adopted by countries, it is possible to observe that the level of liberalization of higher education is slightly higher than the level of liberalization for the average of education sectors. This is a common pattern for most of the member countries and it does not depend on the level of economic development of the countries as can be observed in the Tables 1, 2, 3 and 4. It must be said that I adopt the economic development categories applied by the WTO in its Services Data Base.

XXXXXXXXXXXXX TABLE 1 XXXXXXXXXXXXXXXXXXXXXXX
XXXXXXXXXXXXX TABLE 2 XXXXXXXXXXXXXXXXXXXXXXX
XXXXXXXXXXXXX TABLE 3 XXXXXXXXXXXXXXXXXXXXXXX
XXXXXXXXXXXXX TABLE 4 XXXXXXXXXXXXXXXXXXXXXXX

In the following maps I can compare the general EduGATS with Higher Education EduGATS for all the WTO member countries. The maps show which countries have liberalized education (figure 3) and higher education (figure 2) within GATS, as well as 
to what extend they have done it. The exact value of EduGATS for each country can be consulted in the previous tables. The maps also reflect that Northern Countries usually have greater and more numerous liberalization commitments in higher education, as well as in other education sub sectors. This north-south "gap" will be developed and explained in the next section.

\section{XXXXXXXXXXXXX FIGURE 2 XXXXXXXXXXXXXXXXXXXXXXX}

\section{XXXXXXXXXXXXX FIGURE 3 XXXXXXXXXXXXXXXXXXXXXXX}

Finally, the EduGATS value can be compared depending on the modes of supply and the education sub sectors. In this case, as table 5 shows, trade openness is quite homogenous between the sub sectors, but it is not so similar between the various modes of supply. Specifically, with respect to mode 4 (movement of natural people), commitments are undertaken less intensely as compared with the other modes. This reflects that, within the GATS negotiations, member countries usually reject the acquisition of commitments that could mean the modification of migration rules, visa requirements and other regulations related to the international movement of workers.

\section{XXXXXXXXXXXXX TABLE 5 XXXXXXXXXXXXXXXXXXXXXXX}

\section{The higher education liberalization rationale}

The majority of the WTO members has not yet liberalized Higher Education and other education services in the GATS framework. Specifically, and after health care, educational services is the sector in which the members of WTO have established the fewest commitments on liberalization. The situation is very different in other service sectors contemplated by the agreement, as there are sectors that have been highly 
liberalized, such as tourism and travel services - committed by 129 member countries or financial services - committed by 107 countries $^{4}$.

In order to understand the reasons why liberalization in education advances more slowly than in other sectors, it must be considered that education and, for example, health or water supply are sectors in which the state provision normally predominates and which are fundamental services for the effective implementation of a series of social rights. Consequently, in the framework of the GATS negotiations, sectors of these characteristics are known as "sensitive sectors". In fact, some governments, normally progressive and often under pressure from the civil society, have stated publicly that they will not liberalize this kind of services (Verger and Bonal 2006; Kachur 2003).

In short, the non-liberalization of education opted for by most of the WTO member countries may be influenced by the awareness about the effects of GATS commitments on sensitive sectors. Some of these effects could be the limitation of the regulatory capacity of the states (Robertson, Bonal et al. 2002; Robertson and Dale 2003) or the alteration of the education quality control (Knight 2002; Rodrigues Dias 2002).

Nevertheless, in spite of the fact that there are common elements that hinder liberalization in all member countries, the results of the negotiations in the area of educational services vary widely between members. In order to examine this variation in the countries behavior in GATS negotiations, in the following sections, I analyze the factors associated with the liberalization of higher education and other educational services. I will mainly focus on two hypothetical explanatory factors: a) the characteristics and needs of the member countries' educational systems, and b) the countries' degree of economic development. 


\section{a) Influence of educational-system features}

In this section, I contrast the influence of several characteristics within the education systems with the acquisition and intensity of liberalization commitments, as suggested in some of the existing literature on the topic (Knight, 2002; Larsen et al, 2004; Mundy and Iga, 2003). Specifically, the variables I refer to are the private funding of education (families), state subsidies to the private sector, the enrolment share in the private sector and the foreign students flows abroad (importation of higher education services). The indicators to measure these variables come from OECD (2001) and UNESCO (2006).

After exploring the aforementioned variables related to the characteristics of educational systems, I find out that there are only two of them that maintain a stronger relationship with liberalization. I refer here to the enrolment share in the private sector and to the percentage of state subsidies that the private sector receives. This relation is only contrasted at the level of Higher Education. There is no relation in other education levels. As can be observed in the two figures below, both factors are associated with the establishment of commitments in education, but not with the degree of these commitments (both variables have quantitative values, but in order to ensure greater viability of statistical analysis, I have converted them into qualitative variables.).

\section{XXXXXXXXXXXXXX FIGURES 4 AND 5 XXXXXXXXXXXXXXXXXXXXX}

In the figure 4 , it can be observed how the larger the presence of the private sector in higher education in a country is associated with a lower frequency of establishment of commitments in the educational sector. This may be due to the fact that governments believe the domestic educational supply (state and private) to be sufficiently wide and, consequently, deem it unnecessary to facilitate the entrance of foreign suppliers into 
their educational systems by means of GATS. Another plausible explanation is that, due to its strong position, the private sector has the ability to bring pressure to bear on governments so that they do not liberalize education in the framework of GATS and therefore avoid having to compete with foreign suppliers. Regarding this issue, for instance, Mundy and Iga (2003) document that the lobby of private universities in the USA is very active and effective when exercising pressure on the Congress not to liberalise the higher education sector. Second, as can be seen in the figure 5, those countries that provide more subsidies to the private sector acquire fewer commitments. This relationship may indicate that those countries that heavily subsidize their domestic private sector are not ready to apply the same rules on subsidies to foreign educational centers. Additionally it would be plausible to consider, once again, the pressure brought to bear by the higher education private sector, which would be biased towards nonliberalization and would be motivated by the fact that private centers are not willing to "share the cake" of state funding with foreign suppliers.

On the other hand, I did not find a relation between the 'higher education services level of imports' and the liberalization commitments within the GATS. There are countries that facilitate the trade of education flows because they have adopted a strategy of capacity building and attracting expertise and knowledge from abroad. They would use the GATS and other trade forums to provoke this capacity building process. It seems to be the case of countries such as China and Malaysia (Larsen et al, 2004; Zhang, 2003). But my statistical analysis shows that this is no a policy that could be globally attributed to most of the countries, at least, when only the education trade flows are taken into account. The adoption of this strategy could be more common in developing countries, but I also found out that the non-relation between education 
imports and GATS commitments is a common pattern in all the countries, independently of their level of economic development.

Finally, I neither find that the private funding of education is statistically related to the degree of educational liberalization in the countries studied. This contradicts Mundy and Iga (2003) results, which show that there is a reverse relationship between education liberalization within the GATS and public spending in education. They explain this apparent "paradox" saying that the countries with higher liberalization commitments (which are, very often, developed European countries) "are relatively confident of their national ability to buffer dislocations to educational systems caused by the liberalization" (pp. 312). However, when applying the EduGATS, I do not contrast this statistical association - neither in relation to the education sector in general nor in relation to the higher education level. This difference in the results obtained by Mundy \& Iga (2003) and I are the consequence of the different methods we used and, specifically, on the way of measuring liberalization commitments - see a deeper discussion on this in Verger (2008). Nevertheless, what I want to highlight is that numerous education and social scientists - I include myself among them - are trying to identify education rationales in the countries' trade policy for education and, on occasions, we are forcing some of the explanations and hypothesis. Probably, instead of assuming that, in the GATS context, there is a causal relationship between the education necessities or strategies of the countries, our principal and preliminary research question should be: is there an 'education-oriented rationale' in the GATS negotiations?

\section{b) Influence of countries' degree of development}

The countries' degree of development is strongly related to the establishment of commitments on liberalization in education, both in the education sector and in the 
higher education sub sector. As shown in Figures 6 and 7, the southern countries which is a category that contemplate both developing countries and less developed countries (LDCs) - are more reticent to establish commitments in the area of educational services than are the northern - developed countries and transition countries.

\section{XXXXXXXXXXXXXX FIGURE 6 XXXXXXXXXXXXXXXXXXXXX}

\section{XXXXXXXXXXXXXX FIGURE 7 XXXXXXXXXXXXXXXXXXXXX}

According to the interviews done to the trade negotiators from southern countries, the GATS is perceived, on occasions, as a suitable instrument to attract direct investment and expertise to educational systems, especially for those education levels, in particular higher education, that usually are under-funded by the state. That is, GATS can be a market solution for the limitation on state investment in education. So, why are southern countries much more reticent to establish liberalization commitments on higher education and other education services than northern countries? There are different factors that could explain this, but our first argument is based on the idea that Southern countries should perceive more "threats" or drawbacks than benefits in opening up trade within their education systems.

First at all, it should be considered that developing countries are almost net importers of higher education (OECD 2002). Consequently, educational centers in many of these countries do not only have great difficulties in accessing global educational markets, but trade liberalization may also mean that they are expelled from their own markets by the foreign competition (Barrow, Didou-Aupetit et al. 2003; Rodríguez Gómez 2004). Additionally, many Southern countries should be aware that trade liberalization as envisaged in GATS may introduce considerable complexity - as 
well as limitations - into the area of the domestic regulation and financing of educational systems (Malo 2003). In fact, developing countries do not usually have already suitable legal and technical mechanisms to evaluate the quality of international (or domestic) higher education services. The internationalization of education in many Southern countries has often led to the multiplication of "diploma-mills" or "garageuniversities" (Carnoy 1999; García-Guadilla 2002), terms that indicate the low quality of the services provided. Finally, some southern countries associate GATS commitments to a possible accentuation of the brain drain problem, which is usually a bigger problem for the poor countries than for the rich ones (Knight, 2003; Wende, 2003).

Nevertheless, the development perspective seems appropriate when analyzing the liberalization of educational services in the WTO framework due to other reasons. One of them is that southern countries usually condition their services offers on the outcome of negotiations concerning other issues included in the competences of the WTO, in which they have more offensive interests. I refer to sectors such as agriculture, cotton or textiles. Guided by this rationale, some delegations that have not liberalized education recognize that the educational sector might become a 'bargaining-chip' during negotiations. The bargaining-chip rationale contradicts frontally the education rationale I have just explained. To ascertain which the dominant rationale in the WTO forum is, more qualitative data would be needed. In any case, I have observed that both rationales coexist in the GATS negotiations in the education field.

However, developing countries are not always "less liberal" than developed countries in the education field. If EduGATS is crossed with the 'modes of supply' and the level of economic development variables, it is evident that, as the figure 8 shows, mode 4 (movement of natural people) is the only mode for which the developed 
countries are less 'open to trade' than the rest. To a large extent, this is explained by the fact that rich countries consider establishing commitments in mode 4 to be incompatible with their immigration policies (Saner and Fasel 2003). In contrast, mode 4 is the mode for which many Southern countries would like to see more advances, as they consider that their comparative advantage in the trade in services mainly lies in the export of "human resources" (UNCTAD 2005). Specifically, the interest of the Southern countries in this trade mode is in the income they receive from transfers made by their workers abroad (Shashikant 2005).

XXXXXXXXXXXXXX FIGURE 8 XXXXXXXXXXXXXXXXXXXXX

\section{Conclusions}

Liberalization of higher education and other education services in the framework of trade agreements, such as the GATS, is a new and hot issue in the international agenda of education. Thus, to analyze the rationale of countries' decisions in relation to the liberalization of education becomes more and more necessary. My research, which combines qualitative and quantitative techniques, aims to reveal how different factors and features of the countries are related to the outcomes of the GATS negotiations. Specifically, I have explored the level of relation between several independent variables (higher education public spending, weight of the private education sector, level of economic development of the countries, etc.) with the GATS results in the education sector. The research also shows that the index I have constructed, the EduGATS, is a helpful tool to analyze the state of play of GATS negotiations in the education field. In this article, EduGATS has permitted to us to compare higher education liberalization with that of other education sectors. However, the formula used to calculate the 
EduGATS could also be applied to analyze the liberalization level of other services sectors.

In relation to the latter point, I have found out that, in the GATS framework, higher education has been liberalized at a very similar level as the other regulated education levels (primary and secondary). Higher education is the education sub sector where trade flows are bigger and, consequently, trade liberalization pressures and demands are more intense. Nevertheless, these pressures have not been reflected, until now, in the frequency of the liberalization commitments done by member countries. They have neither been clearly reflected in the liberalization level, as can be observed when the EduGATS is applied.

In relation to the liberalization factors, I have come to two main conclusions. The first one is that, contradicting existing assumptions that are usual in the GATS and education literature, certain characteristics of higher education systems are not statistically related (at least in a way that can be globally extrapolated) with the results of GATS negotiations. The second conclusion is that the North-South divide is an important explanatory factor to understand the GATS outcomes in the education field. Both rich and poor countries perceive common risks to the liberalization of its educational sector in the framework of the Agreement. Among others, I refer to limits on the regulatory space for the states that the establishment of commitments entails, or to the fact that opening up trade in education is a policy opposed by many education stakeholders. Nevertheless, developing countries consider additional elements when negotiating GATS. These countries do not generally have offensive interests in the liberalization of higher education as their universities could hardly be expected to be able to penetrate a highly liberalized global education market. Furthermore, faced with international competition, the southern countries' educational centers would undergo an 
erosion of the market share within their own territories. These and other problems could explain why numerous southern countries tend to adopt a defensive attitude when negotiating education liberalization and, consequently, why there is an obvious gap between the commitments of northern and southern countries in this area. However, many southern countries are considering the liberalization of education in exchange for other countries liberalizing other sectors in which they have more offensive interests such as agriculture or textiles. Therefore, these countries would opt for "sacrificing" their education sector if it means to get benefits in other economic sectors.

After several postponements, the Doha Round and the services liberalization negotiations - as one of the pillars of the round - are still ongoing. Thus, in this moment, there is no available data on the definitive changes in the multilateral trade regime as a result of the Doha negotiations. However, most of the member countries have submitted their first offers on the services area, which become a first valuable source to analyze the global trend of liberalization of education. When checking the already published lists of offers (see the 'WTO on-line documents data base': http://www.wto.org/wto/ddf/ep/search.html), we observe that several developing countries, such as Pakistan, Korea, India, Peru, Colombia, Singapore and Bahrain are willing to open their higher education sector and/or other education sectors to global trade. This means than, after Doha, the existing north-south gap in the liberalization commitments could become smaller. In fact, the list of countries with education commitments could become longer depending on the "level of ambition" - as trade negotiations say - acquired by the round. Anyway, we will have to wait until the end of the Doha Round to extract more firm conclusions on the evolution of the new global regime of trade in education services as well as to more deeply analyze which is the 
'education rationale' (or whether or not there is an identifiable 'education rationale')

behind the constitution of this regime.

\section{References:}

Barrow, C. W., Didou-Aupetit, S. and Mallea, J. (2004) Globalisation, Trade Liberalization, and Higher Education in North America: The Emergence of a new market under NAFTA?, Dordrecht: Kluwer Academic Publishers.

Carnoy, M. (1999) ‘Globalización y reestructuración de la educación’, Revista de Educación, 318: 145-162.

Francois, J. and Wooton, I. (2000) 'Market Structure, trade Liberalization and the GATS', Centre for International Economic Studies. Policy Discussion Paper 3.

García-Guadilla, C. (2002) 'General Agreement of Trade in Services, Higher Education and Latin America', Paper prepared for the Convention of Universities Members of Columbus, Paris, July 2002.

Kachur, J. L. (2003) 'Whose Intellectual Property? Whose Rights? GATS, TRIPS and Education in Canada', Globalisation, Societies and Education 1(3): 375-411.

Knight, J. (2002) Trade in Higher Education Services: The Implications of GATS, London: The Observatory on Borderless Higher Education.

Knight, J. (2003) GATS, Trade and Higher Education Perspective 2003. Where are we?, London: The Observatory on Borderless Higher Education. Retrieved from www.obhe.ac.uk/products/reports/publicaccesspdf/May2003.pdf, 24/05/04

Larsen, K., Martin, J. P. and Morris, R. (2002) 'Trade in Educational Services: Trends and Emerging Issues', The World Economy 25(6): 849-868.

Larsen, K., Momii, K. and Vincent-Lancrin, S. (2004) Cross-border higher education: An analysis of current trends, policy strategies and future scenarios. London: Observatory on Borderless Higher Education.

Larsen, K. and Vincent-Lancrin, S. (2002) 'International trade in educational services: good or bad?', Higher Education and Management Policy 14(3): 2-45.

Malo, S. (2003) 'La comercialización de la educación superior’, in García-Guadilla, C. (ed). El difícil equilibrio. La educación superior como bien público y comercio de servicios, Caracas: Editorial Latina, pp. 101-107. 
Mundy, K. and M. Iga (2003) 'Hegemonic Exceptionalism and Legitimating BetHedging: paradoxes and lessons from the US and Japanese approaches to education services under the GATS', Globalisation, Societies and Education 1(3): 321-357.

OBHE (2002) 'International Branch Campuses: Scale \& Significance', The Observatory on Borderless Higher Education, Briefing Note 5.

OBHE (2003) 'Mapping the Educational Industry (1). Public companies - Share Price \& Financial Results.' The Observatory on Borderless Higher Education, Briefing Note 9.

OECD (2001) Education at a Glance. Education Indicators 2001, Paris: OECD.

OECD (2002) 'Indicators on Internationalization and Trade of Post-secondary

Education', OECD/US Forum on Trade in Educational Services, Washington DC, May 2002.

OECD (2002b) 'Current Commitments under the GATS in Educational Services', OECD/US Forum on Trade in Education Services, Washington DC, May 2002.

Robertson, S., Bonal, X. and Dale, R. (2002) 'GATS and the education services industry: the politics of scale and global reterritorialization', Comparative Education Review 46(4): 472-496.

Robertson, S. and Dale, R. (2003) 'This is what the fuss is about! The implications of GATS for education systems in the North and the South', UK Forum for International Education and Training, Commonwealth Secretariat, May 2003.

Robertson, S. and Dale, R. (2003b) 'Changing Geographies of Power in Education: the politics of rescaling and its contradictions'. GENIE - the Globalisation and Europeanization Network in Education. Retrieved from http://www.genietn.net/genie019.htm, 12/03/05

Rodrigues Dias, M. A. (2002) 'Utopía y comercialización en la educación superior del s. XXI', in Rodrigues Dias, M. A. (ed) Lecciones de la Conferencia Mundial sobre Educación Superior- Perspectivas de la Educación Superior en el s. XXI, Buenos Aires: Siglo XXI, pp. 11-44.

Rodríguez Gómez, R. (2003) ‘La educación superior en el Mercado: configuraciones emergentes y nuevos proveedores' in Mollis, M. (ed) Las universidades en América Latina: ¿Reformadas o alteradas?, Buenos Aires: CLACSO, pp. 87-107.

Rodríguez Gómez, R. (2004) 'Inversión Extranjera Directa en Educación Superior. El caso de México.' Revista Educación Superior XXXIII(2), 130. Retrieved from 
http://www.anuies.mx/servicios/p_anuies/publicaciones/revsup/130/02.html\#e, $15 / 02 / 05$.

Saner, R. and Fasel, S. (2003) 'Negotiating Trade in Educational Services within the WTO/GATS context', Aussenwirtschaft 59(2): 257-308.

Shashikant, S. (2005) 'GATS talks will move only with a "big leap" in mode 4', TWN Info Service on WTO and Trade Issues, 198. Retrieved from www.twnside.org.sg/title2/twninfo198.htm, 17/03/05.

UNCTAD (2005) 'Trade in Services and Development Implications'. Retrieved from http://www.unctad.org/en/docs/c1d71_en.pdf, 12/05/05.

UNESCO (2006) Global Education Digest 2006, Montreal: UNESCO Institute for Statistics.

Van der Wende, M. C. (2003) 'Globalisation and Access to Higher Education', Journal of Studies in International Education 7(2): 193-206.

Verger, A. and Bonal, X. (2006) 'Against GATS: the Sense of a Global Struggle', Journal for Critical Education Policy Studies 4(1). Retrieved from http://www.jceps.com/?pageID=article\&articleID=55, 14/11/06.

Verger, A. (2008) 'Measuring Educational Liberalization. A Global Analysis of GATS', Globalisation, Societies and Education 6 (1): 13-31.

WTO (2000) Guide to the GATS. An Overview of Issues for Further Liberalization of Trade in Services, The Hague: Kluwer Law International.

WTO (2005) 'Initial and Revised Offers. A factual assessment of the sate of play', Council of Trade in Services - WTO.

Zhang, C. (2003) 'Transnational higher education in china: Why has the state encouraged its development?', School of Education - University of Stanford. Retrieved from: www.stanford.edu/dept/SUSE/ICE/monographs/Zhang.pdf, 01/11/06. 
Figure 1. GATS and education sub sectors committed

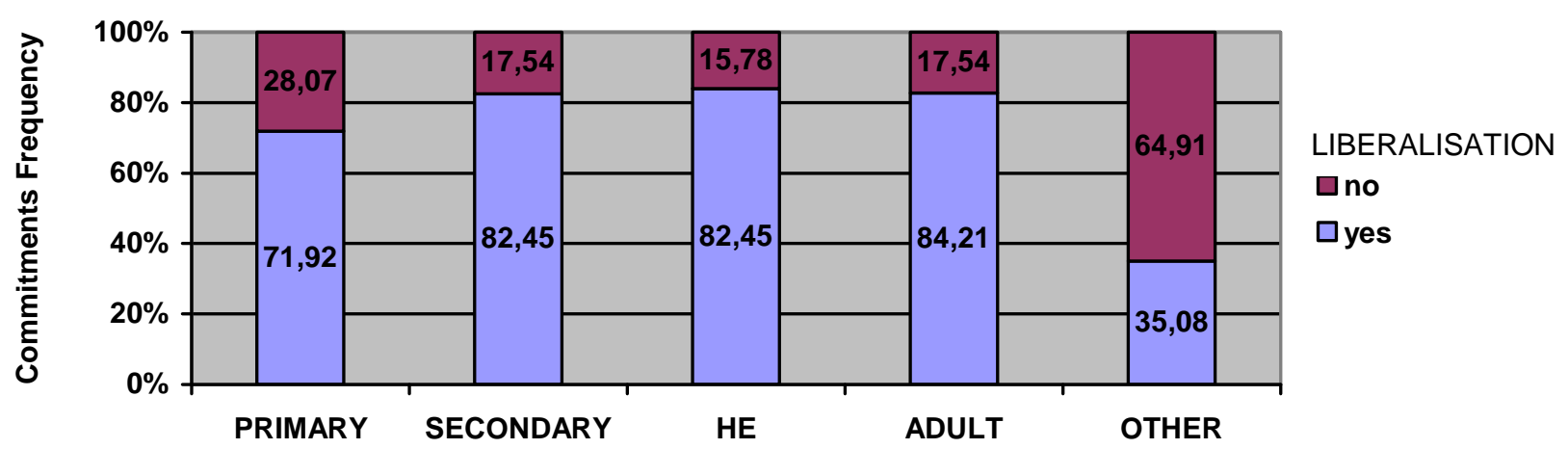

Table 1. EduGATS in developed countries

\begin{tabular}{|ccc|}
\hline Countries & $\begin{array}{c}\text { Higher } \\
\text { Education }\end{array}$ & $\begin{array}{c}\text { Average for all sub sectors) } \\
\text { Australia }\end{array}$ \\
Austria & 0,59 & 0,36 \\
Belgium & 0 & 0,43 \\
Denmark & 0,64 & 0,51 \\
France & 0,61 & 0,49 \\
Germany & 0,55 & 0,45 \\
Greece & 0,62 & 0,49 \\
Ireland & 0,58 & 0,48 \\
Italy & 0,62 & 0,49 \\
Japan & 0,58 & 0,48 \\
Liechtenstein & 0,21 & 0,2 \\
Luxembourg & 0,43 & 0,34 \\
Netherlands & 0,64 & 0,51 \\
New Zealand & 0,64 & 0,51 \\
Norway & 0,66 & 0,39 \\
Portugal & 0,55 & 0,44 \\
Spain & 0,62 & 0,49 \\
Switzerland & 0,6 & 0,49 \\
United Kingdom & 0,7 & 0,4 \\
United States & 0,64 & 0,51 \\
average & 0 & 0,23 \\
& $\mathbf{0 , 5 2}$ & $\mathbf{0 , 4 4}$ \\
\hline
\end{tabular}

Table 2. EduGATS in developing countries

$\begin{array}{ccc}\text { Countries } & \begin{array}{c}\text { Higher } \\ \text { Education }\end{array} & \begin{array}{c}\text { Average for all sub sectors) } \\ \text { China }\end{array} \\ \text { Costa Rica } & 0,42 & 0,42 \\ \text { Ghana } & 0 & 0,11 \\ \text { Jamaica } & 0,81 & 0,37 \\ \text { Jordan } & 0,65 & 0,49 \\ \text { Mexico } & 0,70 & 0,55 \\ \text { Oman } & 0,69 & 0,56 \\ \text { Panama } & 0,57 & 0,55 \\ & & 0,34\end{array}$




$\begin{array}{ccc}\text { Taiwan } & 0,70 & 0,52 \\ \text { Thailand } & 0 & 0,29 \\ \text { Trinidad and Tobago } & 0,33 & 0,20 \\ \text { Turkey } & 0,91 & 0,63 \\ \text { average } & \mathbf{0 , 4 8} & \mathbf{0 , 4 2}\end{array}$

Table 3. EduGATS in less developed countries

$\begin{array}{ccc}\text { Countries } & \begin{array}{c}\text { Higher } \\ \text { Education }\end{array} & \begin{array}{c}\text { Average for all sub sectors) } \\ \text { Congo }\end{array} \\ \text { Cambodja } & 0,76 & 0,15 \\ \text { Gambia } & 0 & 0,44 \\ \text { Haiti } & 0 & 0,45 \\ \text { Lesotho } & 0,89 & 0,20 \\ \text { Mali } & 0 & 0,89 \\ \text { Nepal } & 0,67 & 0,20 \\ \text { Rwanda } & 0 & 0,40 \\ \text { Sierra Leone } & 0,53 & 0,2 \\ \text { average } & \mathbf{0 , 4 0} & 0,53 \\ & & \mathbf{0 , 3 8}\end{array}$

Table 4. EduGATS in transition countries

$\begin{array}{ccc}\text { Countries } & \begin{array}{c}\text { Higher } \\ \text { Education }\end{array} & \begin{array}{c}\text { Average for all sub sectors) } \\ \text { Albania }\end{array} \\ \text { Armenia } & 0,92 & 0,7 \\ \text { Bulgaria } & 0 & 0,34 \\ \text { Croatia } & 0,72 & 0,30 \\ \text { Czech Republic } & 0,38 & 0,52 \\ \text { Estonia } & 0,75 & 0,68 \\ \text { Georgia } & 0,62 & 0,75 \\ \text { Hungary } & 0,70 & 0,52 \\ \text { Kyrgyzstan } & 0,72 & 0,56 \\ \text { Latvia } & 0,87 & 0,58 \\ \text { Lithuania } & 0,77 & 0,69 \\ \text { Macedonia } & 0,67 & 0,61 \\ \text { Moldova } & 0,88 & 0,40 \\ \text { Poland } & 0,62 & 0,88 \\ \text { Slovakia } & 0,67 & 0,50 \\ \text { Slovenia } & 0,65 & 0,67 \\ \text { average } & \mathbf{0 , 6 7} & 0,39 \\ \end{array}$


Figure 2. EduGATS for Higher Education

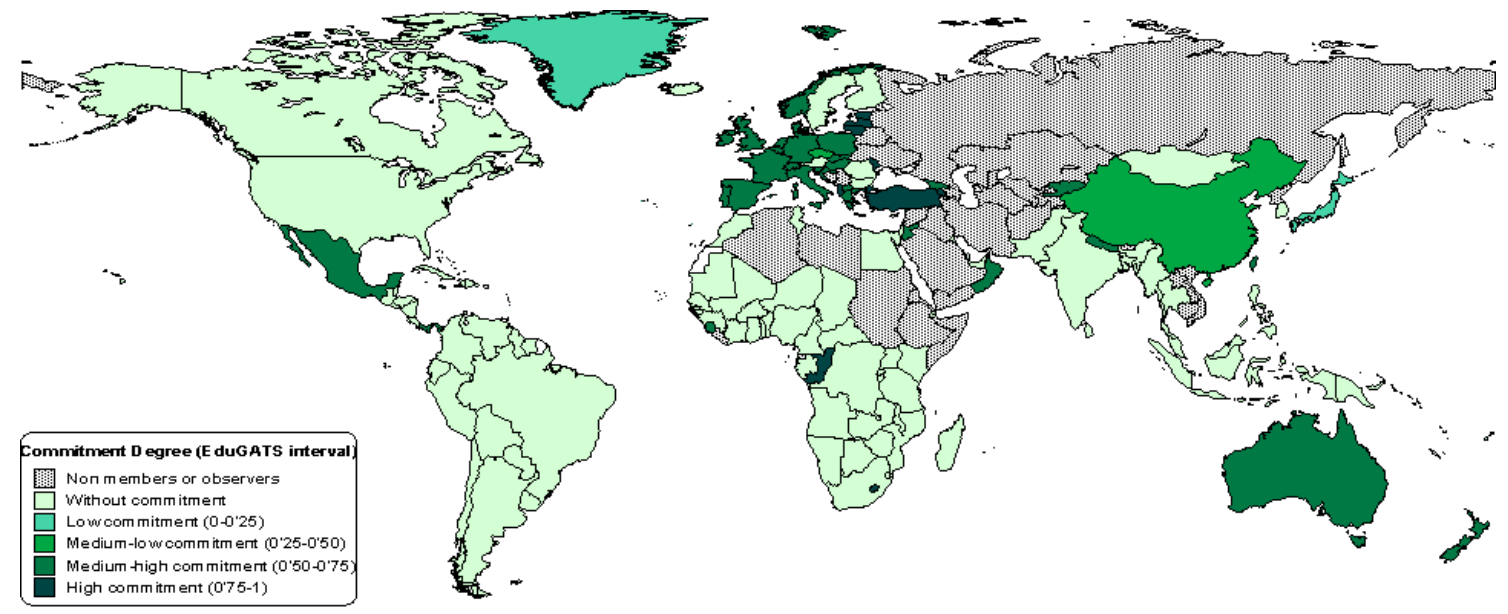

Figure 3. EduGATS for all sectors

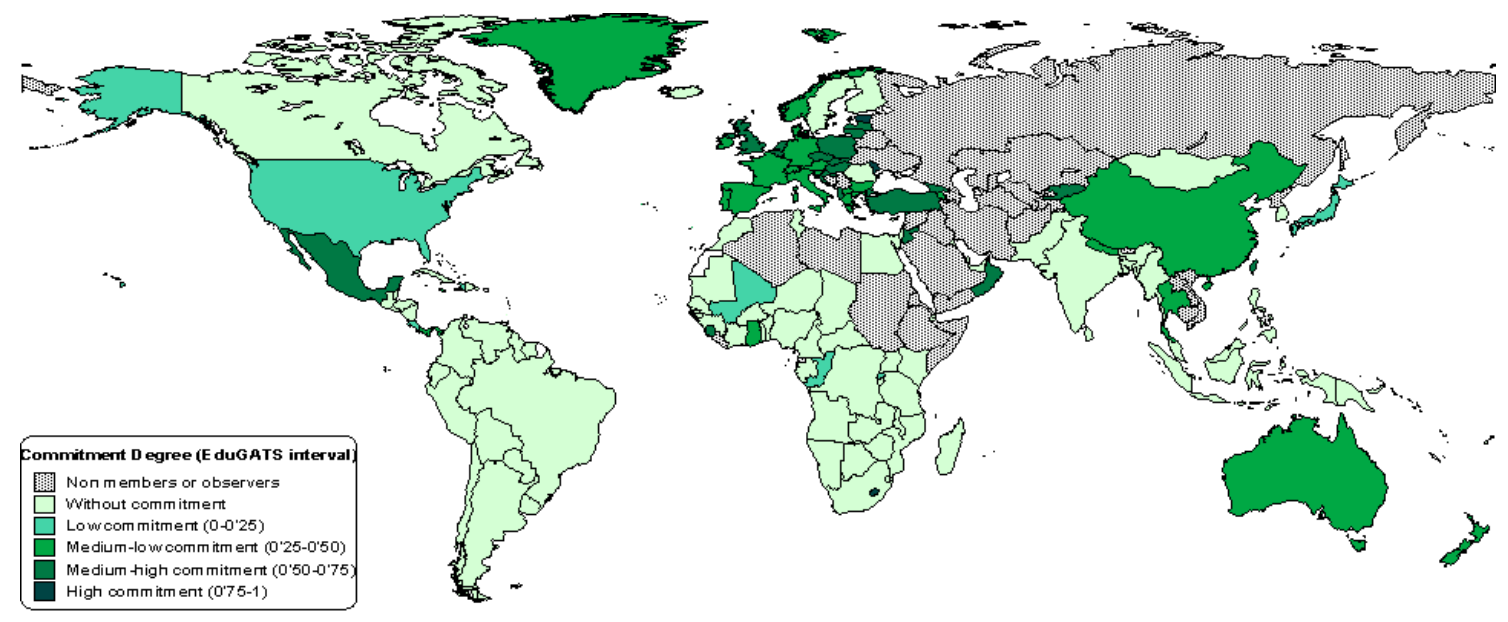

Table 5. GATS commitments in education and modes of supply (EduGATS values)

\begin{tabular}{|l|l|l|l|l|l|}
\hline & Primary & Secondary & $\begin{array}{l}\text { Higher } \\
\text { Education }\end{array}$ & Adult & Other \\
\hline MODE 1 & 0,54 & 0,64 & $\mathbf{0 , 7 1}$ & 0,72 & 0,32 \\
\hline MODE 2 & 0,63 & 0,73 & $\mathbf{0 , 7 3}$ & 0,76 & 0,34 \\
\hline MODE 3 & 0,44 & 0,50 & $\mathbf{0 , 5 1}$ & 0,56 & 0,22 \\
\hline MODE 4 & 0,17 & 0,21 & $\mathbf{0 , 2 0}$ & 0,23 & 0,12 \\
\hline
\end{tabular}


Figure 4. Commitments depending on the weight of the private sector (left)

Figure 5. Commitments depending on state subsidies to the private sector (right)

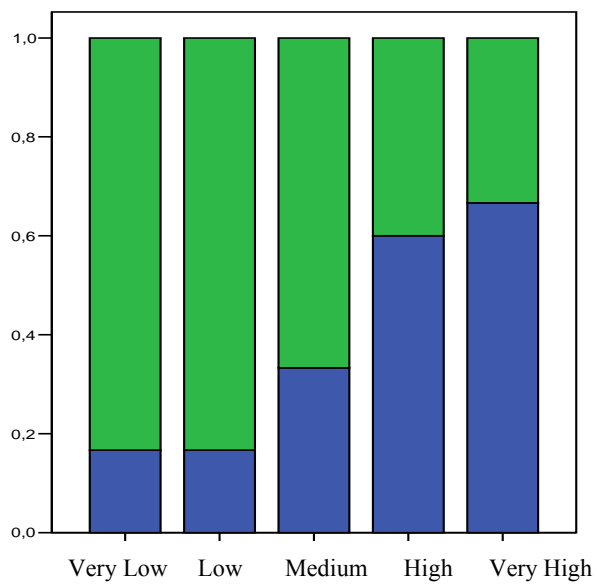

Weight of the private sector

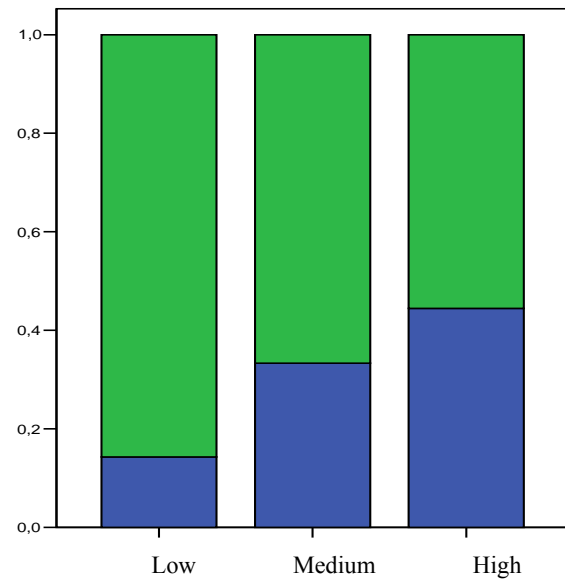

Level of state subsidies to the private sector
Commitments

in higher

education

NO

YES

Figure 6. Commitments on education depending on the degree of economic development

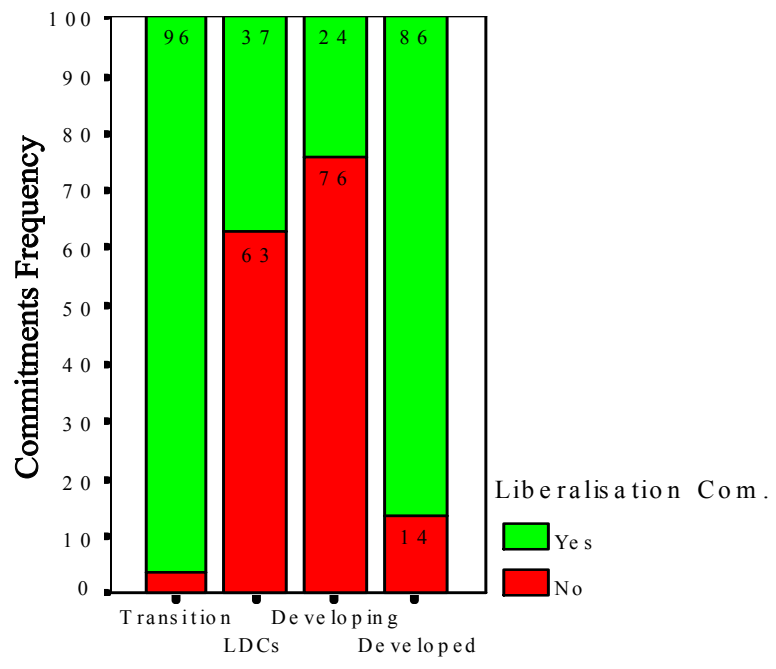

De velop ment Level 
Figure 7. Commitments on higher education depending on the degree of economic development

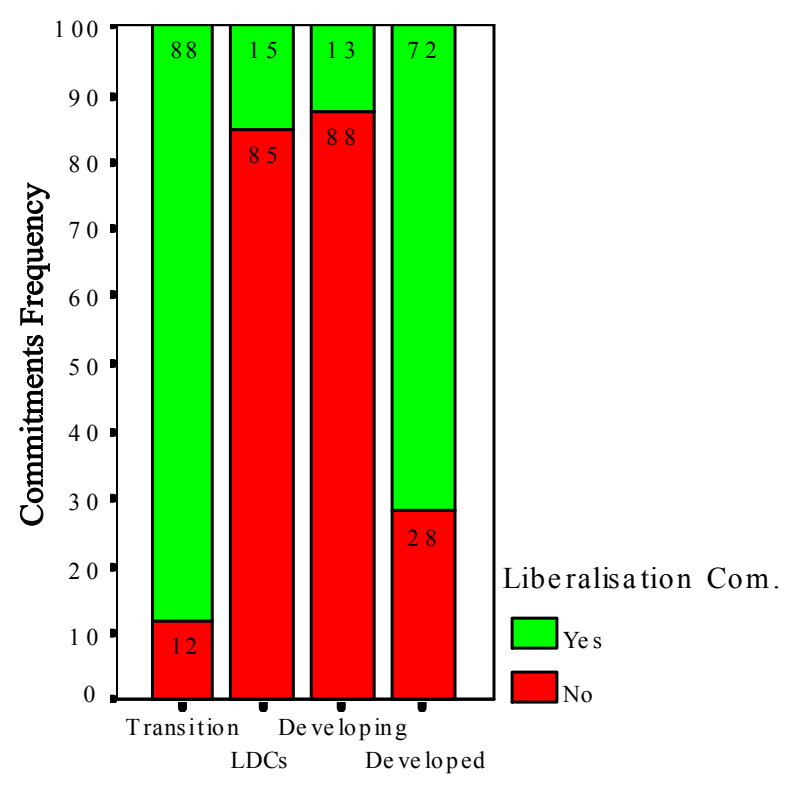

De velop ment Level

Figure 8. EduGATS depending on modes of supply

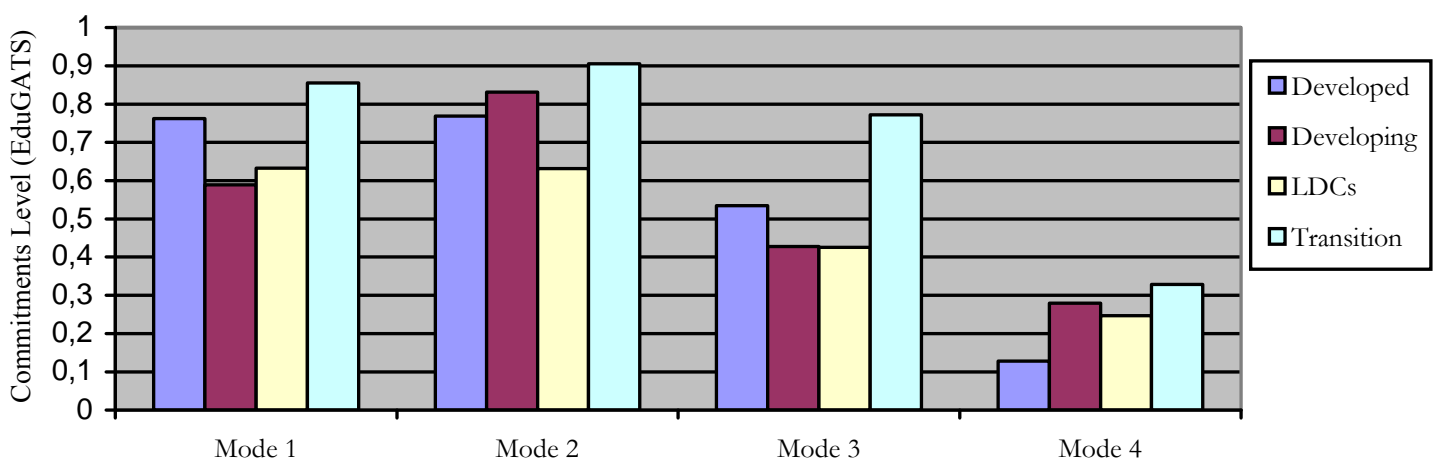

\section{End Notes:}

${ }^{1}$ This article contains results of the project "Más allá de la focalización: Educación, desarrollo y lucha contra la pobreza en el Cono Sur. Análisis de las aplicaciones de la nueva agenda política global en la región" (I+D 2005-2008). Ref. SEJ-04235. An article that contains a general assessment of the liberalization on all the education sectors has been published in the journal Globalisation, Societies and Education 6(1).

${ }^{2}$ The request can be consulted in http://commerce.nic.in/wto_sub/services/Plurilateral_Requests.htm [retrieved: 15/10/06]

${ }^{3}$ In these calculations we do not include the two newest members of the organization: Vietnam and Tonga. Both became formally members of the WTO in the year 2007. See:

http://www.wto.org/english/thewto_e/whatis_e/tif e/org6_e.htm [retrieved: 12/09/07]

${ }^{4}$ In these figures, I include the EU (or European Communities) as a single member - that is, the member countries are not included separately. 